\title{
ORTHODOX EDUCATION IN THE BALTIC PROVINCES OF IMPERIAL RUSSIA AND INDEPENDENT ESTONIA FROM 1840s TILL $1941^{1}$
}

The article is dedicated to the educational activities of the Orthodox church in the Baltic provinces, focusing on the Estonian Orthodoxy. The network of elementary schools, the ecclesiastical seminary and the teaching of Orthodox religion in the secondary schools were the typical forms of Orthodox education before 1917. Despite the break-up of the Russian Empire and the nationalisation of education in Estonia, the Orthodox Church had continued its educational activities. In interwar Estonia this education had bifurcated: the Russian Orthodox had actively engaged with children and youth through the civil society organisations, while the Estonian Orthodox primarily focused on the education of the clergy.

Keywords: The Russian Orthodox Church, the Estonian Apostolic Orthodox church, education, religious instruction, Empire, clergy, schools, the Russian Student Christian Movement, emigration, Russification, secularisation.

Статья посвящена образовательной деятельности православной церкви в прибалтийской губернии, в частности деятельности Эстонской православной церкви. Вплоть до 1917 г. православное образование можно было получить в одной из ряда начальных школ, духовных семинарий и общеобразовательных школ, преподающих основы православной веры. Несмотря на распад Российской империи и национализацию образования в Эстонии, православная церковь продолжила свою образовательную деятельность в стране. Во время межвоенного периода в Эстонии подобное образование разделилось на два направления: Русская православная церковь активно занималась образованием детей и молодежи через гражданские общественные организации, тогда как Эстонская православная церковь сосредоточивалась на образовании священнослужителей.

Ключевые слова: Русская православная церковь, Эстонская апостольская православная церковь; образование; религиозное образование; империя; духовенство; школы; русское студенческое христианское движение; эмиграция; русификация; секуляризация.

\footnotetext{
${ }^{1}$ The article is written with the support of the grant from the Estonian Science Foundation (PUT 428). 
The history of the Russian Orthodox Church, which had experienced revival in the last two decades both in Russia and Anglo-American historical literature, cannot be complete without attention to its educational activities, especially outside its traditional geographical boundaries. This paper aims at bringing the problem of Orthodox education in one of the former provinces of the Russian Empire as a case-study that has important bearing on both the Russian Orthodox Church history and on the history of education.

Following the pioneering work of Gregory Freeze on social history of the Russian Orthodox Church in the 1970-80s [Freeze, 1983; Freeze, 1985] a rich field of the Orthodox Church studies have emerged in the AngloAmerican historiography since the 1990s [Coleman; Dixon, 1993; Kizenko; Kenworthy; Shevzov; Wagner; et al]. Even though the attention to Orthodox education has been marginal within these studies, one cannot fail to mention the work of Laurie Manchester on the formation of the identity of the clergy's sons, whose experience of ecclesiastical seminaries was essential to their collective self imbued by a sense of urgent social mission, moral superiority and martyrdom [Manchester, p. 123-154]. Much of the post-Freezian oeuvres have provided a multi-faceted and often quite positive view of the Russian Orthodox Church. In contrast to these, the recent studies of the Russia's Imperial space have treated the Synodal church as an instrument of Imperial power characterised by intolerance to other faiths. The works of historians of North-Western provinces, including the Great Duchy of Poland and the Baltic realm, in particular, emphasised the role of the church as an agent of the state's interests in assimilating the non-Russian people through the imposition of the Orthodox faith and suppression of religions that were rooted in those lands including Roman Catholicism (including Uniates) and Lutheranism [Dixon, 2004; Долбилов; Skinner; Staljunas; Werth, 2000; Werth, 2002]. Focussing on the Orthodox education in Imperial provinces some of the contradictions can be addressed: has the education sponsored and controlled by the church served the assimilatory aims of the Imperial state; did the Orthodox education seize to exist with the end of the Empire?

Within the Orthodox Church's long historical engagement with nonRussian nationalities the promotion of literacy cannot be separated from the christianisation of the heathen people. However, not until the $19^{\text {th }}$ century that Orthodox impact on non-Russian people of the Empire had resulted in a confessional makeover of the Imperial space. The educational activities of Nikolaj Il'minskij (1821-1891) among the Tatars and Finno-Ugric people of the Volga region are studied better than educational experiments among other non-Russian people [Geraci; Werth, 2000]. Nevertheless, before Il'minskij had initiated his schools in the 1860s, there were already established schools for the Orthodox Latvians and Estonians which carried teaching in native languages. Thus the problem of Orthodox education among non-Russians put forward the question of the vernacular language (both as a language of tuition and the 
language of church service). It seems that at least before the 1890s it was widely accepted that Orthodoxy should be preached through the tongues of the various people of the Empire.

Despite the principle of toleration and voluntary character of conversions, there had always been a danger of insincere conversions and outflows from Orthodoxy, or apostacy, which had to be persecuted according to law. The formal character of religious identification in the Russian Empire was termed by Werth "religious ascription" [Werth, 2000]. Education of the non-Russian Orthodox subjects could not be separated from the problems of conversion and apostasy. The converts lived in an environment that was culturally and religiously antagonistic to Orthodoxy, and maintaining Orthodox faith without receiving some social or economic benefits proved a challenge to many. Orthodox education therefore had to be understood in this context: it meant to integrate converts into Orthodox faith and bring them closer to Russian culture. It was believed to be only possible through the use of the local language in education and liturgy.

The emergence of the non-Russian Orthodox education and culture in the context of the Empire had a potential of cultural and religious autonomy; it seems that the tension between the dominant nationality and minorities had existed within the Russian Orthodox Church already in the $19^{\text {th }}$ century. The secular nationalism had impact on the demands for ecclesiastical autonomy.

Estonia is treated here as a case-study for the understanding of the social activity of the Russian Orthodox Church outside its traditional targetgroup, the rural Russian Orthodox population. The educational projects that emerged within the framework of the Orthodox church in this region shed the light on the strengths and limitations of the social engagement of the church. Estonia, of course, is unique case: here a first chair of the Orthodox theology was established in Tartu University already in the $19^{\text {th }}$ century ${ }^{2}$; education was carried through the means of two languages, Estonian and Russian; the alumni of the Orthodox institutions occupied key political positions after 1918 .

This article will focus on various forms of Orthodox education in the Baltic provinces, focussing on Estonia that included elementary Orthodox schools, teaching of Orthodox religion in public schools, ecclesiastical education and informal work with children and youth. It will cover two major periods: the Imperial (1840-1917) and the period of Estonian Republic (1917-1941). The inclusion of the period of independent Estonia is paramount because it raises the question of endurance of Orthodoxy in the post-Imperial context. How did the breakdown of the Russian Imperial ecclesiastical structure affect the Orthodox education? If the Orthodox Church is understood as a means of Russian Imperial power, how should we evaluate its social and educational activities in the interwar period?

${ }^{2}$ Orthodox religious instruction in the University of Tartu was introduced in 1833, however regular classes started only in 1842. The chair of Orthodox theology was officially established in 1865. 


\section{The Orthodox Education in Estonia: Imperial Period}

In Estonia, the Orthodox education cannot be separated from the conversion movement of the 1840s when - after initial hesitation - the tsarist government had committed itself to the support of the converts and decreed the setting up of Orthodox schools in parallel to the parish system. This was the lower level elementary education that had a clearly expressed pastoral aim. The setting up of Riga Spiritual Seminary in $1846^{3}$ had showed a commitment of the government to provide Estonian and Latvian parishes with the clergy that was locally trained. About two-thirds of the Riga Seminary graduates came not from the ethnically Russian, socially exclusive clergy estate (duhovnoe soslovie), but from the Estonian and Latvian peasantry, which was a remarkable difference compared to other Orthodox seminaries. In addition, the teaching of Orthodox religion in state schools was the law for the Russian Empire.

The Orthodox elementary schools, called the schools of Russian faith, had two types: parish and auxiliary. According to the law, a school had to be set up for an area that had at least 500 Orthodox men and women. By the 1850s Estonian Orthodox had 117 schools. The active development of popular education following the period of Great Reforms 1861-1874, increased funding from central government and the improved administrative control through the Council of Orthodox Schools set up in 1870, teachers' seminaries led to the further increase of the number of Orthodox schools in Ostsee provinces. By the mid-1880s this number increased threefold! According to the calculations of the Estonian historian of education Elmar Ernits the number of Orthodox schools in 1884/85 was 315, with total number of pupils 10439 [Ernits, p. 851-853; Исаков, с. 34]. ${ }^{4}$ Compared with the number of Lutheran schools, the schools of "Russian faith" made up to $26,5 \%$ in Livonia and 7,1 \% in Estonia (before the second wave of conversions in Estonia), and 19,5\% of primary schools in Estonia in total [Ernits, p. 853].

The curricula in the Orthodox schools followed the one set up by the Ministry of Education, but differed from the one adopted for the Russian Church schools after 1884. For example, the Orthodox pupils in Estonia had opportunity to study natural science while their Russian counterparts did not. Estonian schools provided teaching of Estonian (4 hours during first two years) [Отчет, с. 40]. The teaching of religion (6 hours a week) too was carried through the medium of the native language of the pupils. In the 1890s with an intention to increase the number of hours for Russian, the attempt was made to transfer religion in Russian language. This measure proved quite unpopular among the Estonian clergy. Despite the emphasis on the teaching of Russian in the Orthodox schools, in practice, the provision of Russian was uneven. Many schools used the permission to transfer

\footnotetext{
${ }^{3}$ Initially it has been set up as a spiritual school (uchilishhe) and after 1851 as a seminary.

${ }^{4}$ In 1880 there were 395 parish and auxiliary Orthodox schools in three Baltic provinces, in 1887-1888 this number was 465 .
} 
to Russian only during the last year of school, yet many others lacked the resources and qualified teachers [EAA, f. 384, n. 1, s. 1316, lk 48-49].

While the Orthodox schools in general provided a reasonable elementary schooling, and attracted the Lutheran pupils as well as Orthodox, by the late $19^{\text {th }}$ century they have not received sufficient funding to compete with the schools run by the Ministry of Education. Thus the position of the Orthodox school was only slightly better than that of Lutheran schools that had been deprived of the support of the nobility after the Russification reforms.

The graduates of the parish schools with good command of Russian had a chance to study in the Riga Spiritual Seminary whose program was equal in status to state gymnasiums. Despite the Imperial decree on the foundation of the five-class spiritual school in Riga from 1846, the seminary had opened its doors to students in October 1851. The students have been recruited equally from three groups: the children of the ethnic Russian clergy, Latvian and Estonian graduates of parish schools. The curricula of Riga seminary was primarily based on the Russian seminaries only with the teaching of local languages. Under Bishop Filaret (Filaretov, 1877-1882) the Riga seminary had improved its recruitment and teaching staff. The number of scholarship had been increased from 33 to 60; the families of students of peasant origin had been exempted from the payment of taxes and dues. This had increased popularity of Riga seminary among the Estonian and Latvian peasants despite the long period of study and expenses that previously made many parents hesitant about sending their child to Riga for no less than 8 years! [Гаврилин, p. 270]. Under Filaret the teacher salaries increased too: from 1000 roubles a year in 1851-1856 to $1300-1400$ roubles [Ibid, c. 271].

The level of education received in Riga Seminary was relatively high, as many graduates could continue education in universities. According to calculations of Anu Raudsepp, 21 \% of Estonian graduates from RVS received higher education (compare to $7 \%$ Tartu Teacher Seminar graduates who received higher education). However, compared to the education of the Lutheran clergy who graduated from the Theology department of Tartu university, the Orthodox priests appeared less able to engage in interconfessional disputes. On the other hand, because the priests of Estonian and Latvian origin (as well as many priests of Russian origin who became rooted in the Baltic provinces) came from the peasants, they shared culture and social experience with their parishioners. Between 1847 and 1918 at least 663 Estonians had studied in the Riga Spiritual Seminary, many of whom became not just priests but leading figures in education and administration [Raudsepp, p. 153].

What was the experience of the seminary like? Laurie Manchester, for example, argued that despite the criticism of Bursa (a degrading term for the Orthodox seminary) by the writers such as Nikolaj Pomyalovskij (1835-1863) many autobiographers "actually idealised certain aspects of bursa life, such as comradeship, leisure, patriarchy, paternalism, self-ed- 
ucation, and ironically, their suffering" [Manchester, p. 154]. The Latvian student of the seminary in Riga Pavlis Gruzna in his autobiographical "Bursaki" presents the atmosphere in the seminary as both patriarchal and riveted by tensions. The students from Latvia were not allowed to sing their folk songs, because it was regarded as pagan, nor to read Latvian language newspapers. The half-literate servant in the seminary did not make a distinction between Latvian and Estonians, considering them Germans. Yet, unlike Pomyalovskij's recollection, Gruzna did not condemn his alma mater. On the contrary, he provides portraits of the seminary teachers that were patriarchal, sometimes comic but sympathetic. For example, there is a humorous portrait of an old priest-confessor Nikita, who was so innocent that he naively believed all lies his students told me. He also tolerated mischief: once students replaced his bottle of wine with a bottle of ink, to make him wonder whether it was God's punishment for his sins [Инфантьев, c. 162]. How did the seminary affect careers of their graduates? Many of the Estonian seminary graduates who studied in Riga in the 1880-90s had become prominent in the political and cultural life of the Republic of Estonia. Among the Estonian graduates of Riga Spiritual Seminary were Konstantin and Nikolai Päts, Jaan Poska, Ado Birk, Theodor Rõuk, Tõnis Vares.

\section{Teaching Orthodox Religion in City Schools}

As is known, morning prayers and religious instruction (Zakon Bozhij,) had been an important part of secondary education. Yet the share of religious instruction (usuõpetus) in the school curricula began to decline during the last years of Tsarist era. Compared to the 1870s when it occupied 5-6 hours a week, in 1913-1917 the number of hours for religion was 2-3 hours a week.

Religion was an obligatory subject in all Imperial state schools. The mixed confessional background of the school-children in the Baltic provinces caused some problems with the teaching of religion. In the parish schools that were funded by church and by rural councils, confessional differences had to be addressed: the Lutheran children who studied in the Orthodox schools had to learn Lutheran catechism. In the Lutheran schools that came under the Ministry of Education, a presence of Orthodox children had caused concern for the authorities. They argued that such children had the right to the Orthodox tuition, and the right to study in such schools in general. It was ruled that the Lutheran schools had to notify an Orthodox priest about Orthodox children in their class [Приложение, c. 5-7]. The priests had to attend the schools to provide catechism and ensure that such children had made annual confession and took communion. According to the Manifesto on Religious Tolerance in 1905 children of minority faiths (including Old Believers) could demand a religious instructor of their own confession [Сборник, с. 210]. In that case, it was the parents that had to pay to the teacher. It is noteworthy, however, that the members 
of minority faiths had received the right to study in teachers' seminaries that had been founded by the Orthodox Church [Сборник, с. 219].

After the revolutionary crisis of 1905-1907, facing general secularisation of society the state made an effort to strengthen religious instruction regardless of confession. Moral and religious upbringings of youth combined with physical development were deemed to be the goals of education, leading to "national renewal and improvement of national health" [Ibid, c. 191]. Efforts have been made to implement new methods of teaching and generally strengthen the quality of religious instruction. In 1909, for example, the national congress of the Orthodox religious instructors that took place in St Petersburg had worked out a program of improvements of confessional teaching. In Riga Teaching District the summer courses for teachers had been addressed to teachers of religion too. For example, in 1913-1914 the teachers of religion attended the summer courses organised in Viljandi (Fellin) and Kuuresaare (Arensburg). In 1913 in Viljandi Summer courses priest Nikolai (Luzik) had presented new methods for teaching religion to Orthodox pupils. He evaluated the positive and negative sides of three contemporary methods of organising the material: gradual, combined and concentrical, as well as discussing three teaching techniques, akroamatic, heuristic and dialogical, their specific features and applications [EAA, f. 384, n. 1, s. 2221, lk. 60].

\section{Orthodox Education and Estonian Independence}

The birth of the Republic of Estonia in 1918 resulted in many notable changes in the field of education, including the elimination of Orthodox elementary schools. The closing of these schools had begun already in 1917 at the time of German occupation when the Russian central government was unable to continue supporting such schools and the German military authorities tried to impede Orthodox education in the Baltic provinces by shutting down Orthodox schools or handing them over to Lutherans. On 19 November, 1918, after the end of the German occupation the Estonian Ministry of Education decided to return all former Orthodox schools to their original owners, i. e. Orthodox parishes. On 27 December, 1918 the Ministry clarified that all such schools may continue operating as private schools and they will not be forcibly nationalised. However, in cases where parishes did not have sufficient means to continue providing elementary education they were allowed to turn to county administrations, asking the schools to be nationalised [Õigeusu koolide kohta, p. 6]. Although there were a few Orthodox schools that attempted to survive as private schools, most such attempts resulted in failure and the majority of Orthodox schools were turned into public elementary schools, governed by the Elementary School Act of 1920. These schools did not operate any more on confessional basis [Avalikkude algkoolide]. In a letter from 7 March, 1919 the Ministry of Education had allowed the hiring 
of Orthodox priests and sacristans as teachers in public schools, provided they had official qualification as teachers and could devote enough time for teaching. At the same time the Ministry recommended hiring candidates who were not employed somewhere else and could therefore teach full time [Kõrvalistest ametitest, p. 23]. Based on this recommendation the school boards of county administrations often refused to register Orthodox clergy for teaching in public schools. As such cases occurred mainly in areas with Lutheran majority, many Orthodox priests and sacristans came to interpret it as one form of discriminating against the Orthodox believers [EAA, f. 1655, n. 3, s. 251, lk. 290-291, 328].

Religious education that had occupied a central position in the curriculum of all schools was designated as a voluntary subject by the Provisional Government on 2 December, 1918 [Eesti Ajutiste, p. 20]. The Constituent Assembly elected in 1919 was dominated by Social Democrats and another left-wing movement, the Estonian Labour Party. The Assembly moved to abolish religious education in public schools completely. The second paragraph of the Elementary School Act from 2 May, 1920 declared that education in elementary schools was to be free, in the native language and without religious instruction. In the same year the Minister of Education Jüri Annusson from the Labour Party prohibited all religious ceremonies on school premises. The Secondary School Act approved by the Riigikogu (parliament) in 1922 would have abolished religious education also in secondary schools. These decisions caused outrage among both Lutherans and Orthodox. The majority of the population did not support the removal of religious education from the curricula and the official protests by clergymen were supported also by common lay people. When the proposition to restore religious education to schools put forward by the Lutheran-dominated Christian People's Party failed in the Riigikogu in autumn 1922, a referendum was organised. It took place on 17-19 February, 1923. Referendum drew 461005 votes, 328369 of them in support of restoring religious education to schools [Haava; Valk, p. 22-31]. The desire of the people was confirmed in an amendment to the Elementary School Act that came into force on 19 March, 1923 [Asutava; Valk, p. 34-35]. ${ }^{5}$ It is interesting to note that although the majority of Orthodox believers supported the restoration of religious education, some clergymen also invited people to vote against it. The religious education in Estonian schools could be either denominational (where there were at least 10 members of the same religious group in the same grade) or interdenominational. Some Orthodox priests and lay activists were worried that as Orthodox children formed a minority in most schools and as most teachers of religion were Lutherans, their children would be forced to learn Lutheran doctrines anyway. The Orthodox Church contacted repeatedly the Ministry of Education where the issue was investigated thoroughly; however, no proof for such allegations was found

${ }^{5}$ The Secondary School Act was to come into force only in autumn 1923 and therefore it did not require an amendment, just nullification of the paragraph regarding the abolishment of religious education. 
[EAA, f. 1655, n. 3, s. 251, lk. 72]. ${ }^{6}$ The general principles for providing religious education remained unchanged until 1940, only the structure and accents of the curricula were revised: for elementary schools in 1931 and 1937, for secondary schools in 1925 and 1938 [Valk, p. 71-91].

In the early years of the Republic of Estonia the training of priests was another issue that had to be solved. The Riga Seminary had been evacuated due to approaching front to Russia in 1915 and this evacuation had ended the training of Orthodox priests in the Baltic provinces. Even if the Seminary were still in existence, many Estonian Orthodox priests had deemed its curriculum outdated and had demanded already back in 1917 that the training of priests should be transferred to a university, similarly to the training of Lutheran pastors [EAA, f. 1655, n. 3, s. 62, 1k. 8]. First steps in that direction had been made by the Vicar Bishop of Tallinn, Platon (Kulbusch). He had turned in spring 1918 with this request to the University of Tartu and had been granted an approval by the Council of Professors in May 1918. However, due to war the founding of the Chair of Orthodox Theology was postponed and it was officially opened only with the decision of the University Board on 7 September, 1919 [EAA, f. 1655, n. 3, s. 243, lk. 428, 431]. At first no decision was made about which faculty the Chair should belong to - only in 1925 it was designated as part of the Faculty of Theology. In autumn 1919 Archpriest Karp Tiisik, a graduate of the Moscow Theological Academy became the first holder of the Chair. However, Tiisik passed away on 30 June, 1922. After his death Archpriest Vassilij Martinson was presented as a new candidate for the Chair. He was a graduate of the St. Petersburg Theological Academy, had served as Rector of the St. Petersburg Seminary in 1910-1918 and had only recently returned from Russia to Estonia. Martinson started his work at the University in October 1922 and became a Full Professor in 1931 [EAA, f. 2100, n. 2, s. 615, lk. 6-8, 48]. Students studying Orthodox theology were required to subscribe to the general curriculum of the Faculty of Theology and pass the same exams as other, Lutheran students. Only a handful of subjects were taught by the Chair of Orthodox Theology: dogmatics, systematic theology, canon law and history of the Orthodox Church in Eastern and Baltic countries. The Professor of Orthodox Theology also supervised their training in systematic theology and a seminar in practical theology, graded an essay and took tests in catechetics and homiletics [EAA, f. 1655, n. 3, s. 243, lk. 103-104]. Due to high academic requirements and high tuition fees the Chair of Orthodox Theology was plagued by scarcity of students, not alleviated even by scholarships provided by the Church and congregations. In years 19251940 there were only 29 full-time students and only five of them graduated:

${ }^{6}$ According to the Ministry there were $80.2 \%$ of Lutheran students and $19.1 \%$ of Orthodox pupils in elementary schools. The percentage of teachers was 79.1 for Lutherans and 20 for Orthodox. In secondary schools there were $88.4 \%$ of Lutheran pupils and $84.9 \%$ of Lutheran teachers, $11.2 \%$ of Orthodox pupils and $12 \%$ of Orthodox teachers. Therefore the Ministry concluded that actually there were more Orthodox teachers than Orthodox pupils and the cases where Orthodox pupils were taught religion by a Lutheran teacher should have been very rare. 
Vladimir Karinskij and Rostislav Lozinskij in 1934, Aleksandr Osipov and Edvald Õunapuu in 1935, Aleksander Jürisson in 1938. Lozinskij, Osipov and Jürisson also became priests. Four other students - Theodor Bleive, Nikolaj Hindov, Vitalij Tähe and Artemij Pops - were elected and ordained priests before graduation and had to drop out in order to start serving their congregations [EAA, f. 2100, n. 2, s. 615, lk. 92]. At the same time the Synod of the Estonian Apostolic Orthodox Church (EAOC) estimated that every year they needed at least five candidates for priesthood from the University [Ibid, f. 1655, n. 3, s. 243, lk. 162]. Therefore the Chair failed to fully meet the expectations of its founders.

As the EAOC came to a conclusion that smaller rural congregations do not necessarily need people with higher education as priests, some clergymen had already in 1919 come up with an idea to found a theological secondary school or a seminary. However, over the course of many years this idea was hindered by the lack of finances and appropriate facilities. Only in 1929 the Church Council made an official decision to open a seminary but even then the process took more than 3 years to complete [Laar]. The new institution of education was opened on 3 September, 1933 with a festive meeting and prayer service by the Head of the EAOC, Metropolitan Aleksander (Paulus). The first academic year began two days later. The Seminary was located in the Petseri Monastery where it had a classroom, two dormitories, a washing room, a wardrobe and a teachers' room at its disposal. Nikolai (Leisman), Bishop of Petseri and Superior of the Petseri Monastery, was appointed as Rector of the Seminary. Everyday business of the Seminary was carried out by his deputy, Archpriest Joann Paavel. When Paavel became ill, Archpriest Joann Envere was appointed as new deputy in November 1939. The duration of studies was two years and the curriculum was designed to provide a wide theoretical and practical training for future priests through the medium of Estonian language. The theoretical part of the curriculum included moral theology, exegesis, dogmatics, philosophy, church history and comparative religious studies. The practical side of the curriculum covered church music, homiletics, Estonian and Russian but also the basics of economics, gardening and first aid [EAA, f. 1655, n. 3, s. 361, lk. 675-676]. In 1934 didactics and pedagogy of religion were added to the curriculum. However, the Seminary was not certified to give qualification to teach religion at schools. That is why students who wanted to become teachers had to take additional two year course in the pedagogical colleges in Tallinn or Tartu [Ibid, s. 361, lk. 299, 308]. The Seminary accepted secondary school male graduates men not older than 40 years. Men who had only elementary education could attend classes without becoming full students. If they passed all the required tests, they were considered qualified to work as sacristans. Ten seminarians had full support from the monastery, others had to pay a relatively low tuition fee of 15 Estonian Kroons a month [Ibid, s. 361, lk. 578]. A light curriculum, reasonable academic requirements and low costs resulted in a high number of candidates and seminarians. Already 
in the first year 50 young men applied to the Seminary, 20 of them were admitted. At first new seminarians were admitted every two years but from 1938 onwards a new course was opened every year. All in all there were 45 graduates of the Seminary, most of whom found work as clergymen [EAA, f. 1655, n. 3, s. 361, lk. 24-25, 55, 176, 263, 354]. Most of the seminarians were ethnic Estonians, however, there was always also a minority of Russian-speaking seminarians. In 1936 there were 12 Estonians and 5 Russians. In 1937 there were 7 Estonians and 4 Russians. In 1939 there were 10 Estonians and 6 Russians.

\section{Orthodox Education and the Russian Diaspora in Estonia 1917-1941}

Even though Estland and Liivland had a number of ethnic Russians before 1917, as a result of the war and revolution Estonia had acquired a much larger proportion of the Russian-speaking Orthodox population that comprised the members of the White armies, refugees from the Soviet Russia, as well as the peasant population of Petseri and Narova River (Prinarov'e) region. The refugee part of this population was in flux: many have stayed in Estonia temporarily before moving to the West European countries. There was also a network of social and family connections between the Russian emigrants in European countries. Overwhelmingly the emigrants, who came from the middle or upper classes, have received a good education and wanted their children to have the same. The instability, poverty and trauma of revolution have led these men and women, who may have not been before very religious, to turn to the Orthodox Church. The emigrant organisations focused their efforts on youth and children, hoping to infuse them with Orthodox values and love for Russian culture. The leading role was played the Russian Student Christian Movement that had support of YMCA and World Christian Student Federation. The congress of the Russian Student Christian Movement (hereafter RSCM) in Psherov near Prague in 1923 had marked a new stage in the cooperation between the Western Evangelical Christians and the Russian emigrant youth: the charismatic presence of father Sergij Bulgakov and other Orthodox speakers made the connection with the Orthodox church very palpable. ${ }^{7}$ The RSCM operated as a confederation of national organisations, representatives of which gathered at regular conferences. In Estonia, the RSCM circles emerged on the basis of the YMCA/YWCA network in Tallinn, Narva, Tartu and Petseri, incorporating the Christian Union of the Russian Students in Tartu [Шувалова, с. 194].

${ }^{7}$ The origins of RSCM (Russkoe Studencheskoe Hristianskoe Dvizhenie) go back to 1905 when YMCA founded a Russian branch "Lighthouse" (Mayak) in Moscow with Marcinkovskij as the leader. In 1913 the Russian branches were transformed into the Russian student Christian movement. 
The work of the RSCM among children and youth consisted of the organisation of the Bible-study groups ${ }^{8}$, kindergartens and Sunday schools, and scout organisations: "Vityazi" for boys and "Druzhinnici" for girls. These Orthodox scout organisations for children from the age 12 to 18 had their own summer camps where prayer and sermons were part of the programm. The girls scouts wore uniforms: navy blue shirts, the same colour skirts and a white neck-scarf. In the morning a girl-scout put two knot on her scarf. If during the day she made two good deeds, she was allowed to undo the knots [Ганьжин].

Even though schools had state program in which the teaching of religion had been made optional and non-confessional, the Russian schools had retained their connection with the Church. In the Russian gymnasium in Tallinn the prayer was said before the start of classes, and icons carried out solemnly by the school children. The Russian private elementary school (1-4 grades), run by the organisation "The Russian Child's House" was located in the church house of Kasan Nativity of Mother of God church in Tallinn. The head of the school was Tat'yana Dezen, an active member of the RSCM. According to the memoir of Metropolitan Kornelius (Jakobs), it was thanks to Dezen's moral influence that he had made a commitment to church. Priest Aleksandr Osipov had run a Bible-group in the Kazan church every Sunday, which attracted many young people.

Among the active leaders of the RSCM in Estonia were I. A. Lagovskij (1889-1941), the Dezen family (especially T. Dezen), T. M. Fomina, T. Milyutina (Bezhaniczkaya). The organisers and active force of the movement were lay people. In addition, the majority of the Russian-speaking priests of EAÕK participated in the activities of the RSCM including Fr Ioann Bogoyavlenskij, Fr Rostislav Lozinskij and Fr Alexandr Kiselev. Bishop Pavel (Dmitrovskij) was the confessor of the RSCM in Narva. Priests Alexandr Osipov and Anatolij Ostroumov were also involved in many activities of the RSCM.

In Petseri region the Russian Christian Movement of Peasant Youth had been launched by one of the members of RSCM Ivan Pen'kin who worked as a primary school teacher in Petseri, organising a dormitory for poor children whose families could not afford sending children to school. The Estonian state had appreciated the educational and missionary work among the peasant population in Petseri and promised to provide some material support for "the peasant youth" movement.

The problem of Christian education and catechisation of youth had been pressed by the Russian clergy. During the diocese conference in 1939 Bishop Pavel (Dmitrovskij) of Narva had criticised the teaching of religion in state schools in Estonia, pointing out that often this subject was taught by teachers who were not practicing believers. He believed that the clergy had to have a larger role in teaching religion at schools [Второй Пастырский

${ }^{8}$ These groups were not called "Bible-study", but they focussed on the reading the Gospel. The members of RSCM organised such groups among the young people. See footnote below. 
съезд, с. 196]. During the same conference Fr Rostislav proposed a programm of catechisation of youth that comprised 33 hours and included the New Testament, church history and the liturgy. This was analogue of the Lutheran confirmation classes was intended for 15-16 years old youth and was to take place during Great Lent. ${ }^{9}$

The Russian Student Christian movement meetings in Tallinn took place in the underground floor of the Aleksander Nevskii Cathedral, which had been named jokingly "catacombs". Estonia hosted two annual congresses of RSCM: in Petseri in 1929 and in 1930, and in Dormition of Mother of God Pjuhtitsa Convent in Kuremäe in 1932, attended by father Sergij Chetverikov, archpriest Pavel (Dmitrovskij), father Vasilij Zen'kovskij and mother Mariya (Skobczova). The Estonian press gave negative reviews of the congress, suggesting that this was a gathering of the Russian nationalistic pro-monarchist youth [Плюханов, с. 201-230]. In 1934 the congress of the peasant youth in Estonia gathered in Räpina which was attended by 70 representatives.

\section{Conclusion}

In contrast to the studies that emphasise the instrumental role of the Russian Orthodox church in the non-Russian provinces of the Russian Empire, this article proposes to focus on the social activity of the Orthodox church in one of the Baltic provinces as largely driven by social demand rather than Imperial policies. It argues that the Orthodox education in Estonia emerged as a response to the needs of the young Orthodox parishes that faced an unequal competition with the Lutheran parishes and schools that had more material and cultural resources. Even though the Orthodox education had received funding from the central state, it served the needs of the local population, allowing the formation of the native intelligentsia and an autochthonic ecclesiastical culture. During the nineteenth century the network of the Orthodox elementary schools had grown, teachers' colleges existed for the talented graduates of parish schools, while the candidates for the clergy could study in Riga Spiritual Seminary. While the elementary education was largely through the medium of Estonian, in the secondary institutions it was through the medium of Russian. Starting from the era of Alexander III the aim of the education, including Orthodox schools, had become more assimilationist, placing the Russian language not Orthodoxy - as the means of integration of non-Russian people of the

9 The Lutheran confirmation (leer) took place twice a year, in spring and in autumn, but it depended if there were enough youngsters in the parish for holding it twice a year. Usually it was completed before the $18^{\text {th }}$ year of life, most attendees were $15-16$ years old. The courses could last from 2 weeks to 3 months. In many Orthodox congregations it was organised in a similar way already in the late $19^{\text {th }}$ century (http://www.eelk.ee/ eelk96/tekstid/sundmused.htm). 
Empire. This had been followed by the growing secularisation after the revolution of 1905-1907: the number of hours for religious instruction has been reduced, Orthodox schools generally underfunded, while many graduates of the spiritual seminary taking the path of secular salvation. All in all, the Orthodox education sponsored by the church and the Imperial state had been in crisis by the beginning of the First World War.

The break-up of the Russian Empire in 1917 did not lead to the disappearance of Orthodoxy, but rather to the emergence of a local Orthodox church with two clearly expressed ecclesiastical and linguistic cultures within it, one shaped by the Russian-speaking parishes, another by Estonians. The educational efforts of the Russian and Estonian-speaking parts of the EAOC in 1917-1941 developed independently, even though, the clergy - both Russian- and Estonian-speaking - was trained in the same institutions. However, what concerns the education of children, the Russian émigrés have been more active than the Estonian Orthodox: the activity of the Russian Student Christian Movement have resulted in the emergence of new educational forms, children's and youth movement, pedagogical theories and creative exchange between contemporary Western Christian and Orthodox educationalists. All of these, of course, came to an end in 1941 with the occupation of Estonia. The Soviet period is characterised by the Russo-centric forms of education, primarily the clergy training and the stagnation of all other forms of religious work with children and youth.

Второй Пастырский съезд Нарвской епархии в г. Нарве 10-11 августа 1939 г. Выборки из протокола // Православный собеседник. 1939. № 9. С. 126. $368 \mathrm{c}$.

Гаврилин А. Очерки истории Рижской епархии (19 век). Рига: Филокалия, 1999.

Ганьжин С. Уроки мудрости // Журнал Московской патриархии. 2002. № 6. URL: http://www.srcc.msu.su/bib_roc/jmp/02/06-02/12.htm

Долбилов М. Русский край, чужая вера: этноконфессиональная политика империи в Литве и Белоруссии при Александре ІІ. М.: НЛО, 2010. 999 с.

Инфантьев Б. Неприязни и конфликты между русскими и латышскими православными семинаристами в 80-е - 90-е годы: По роману Павила Грузны «Бурсаки» // Русский мир и Латвия. 2011. № 27. С. 160-163.

Исаков С. Г. Русский язык и литература в учебных заведениях Эстонии XVII-XIX столетий. Вып. 2. Тарту, 1974. 226 с.

Отчет о состоянии православных народных училищ Прибалтийских губерний за 1904-1905 учебный год // Рижские епархиальные ведомости. Приложение. 1906. № 11-12.

Приложение к № 3 циркуляров по Рижскому учебному округу за 1903 г.

Плюханов Б. В. РСХД в Латвии и Эстонии: Материалы к истории Русского Христианского Студенческого Движения. [Париж]: YMCA-Press, 1993. 311 с.

Сборник распоряжений по Рижскому учебному округу (13.04.1911). Рига: Типография А. Нитавского, 1913. 480 с.

Шувалова E. Начало деятельности Русского Студенческого Христианского Движения (РСХД) в Эстонии // Русские в Эстонии на пороге XXI в. Прошлое, настоящее, будущее / ред. В. Бойков. Таллинн, 2000. С. 193-199.

Asutava Kogu poolt 2. mail 1920 a. vastuvõetud algkooli seaduse muutmise seadus // Riigi Teataja. 1923. № 35/36.

Avalikkude algkoolide seaduse eelnõu // Kasvatus. 1919. № 1. P. 6-16. 
Coleman H. Orthodox Christianity in Imperial Russia. A Source book on Lived Religion. Bloomington: Indiana University Press, 2014. 333 c.

Dixon S. Church, State and Society in Late Imperial Russia: the Diocese of St. Petersburg, 1880-1914: PhD diss. London: University of London, 1993. 300 c.

Dixon S. Sergii (Stragorodskii) in the Russian Orthodox Diocese of Finland: Apostasy and Mixed Marriages, 1905-1917 // The Slavonic and East European Review. 2004. Vol. 82. № 1. P. 50-73.

EAA - Eesti Ajaloo Arhiiv. F. 384, 1655, 2100

Eesti Ajutise Valitsuse määrused koolide kohta // Kasvatus. 1919. № 2.

Ernits E. Õigeusu koolid 1840. aastatest 1880. aastate koolireformideni// Nõukogude kool. 1973. № 10. P. 847-854.

Freeze G. Handmaiden of the State? The Church in Imperial Russia Reconsidered // Journal of Ecclesiastical History. 1985. Vol. 36. № 1. P. 82-102.

Freeze G. The Parish Clergy in Nineteenth-Century Russia: Crisis, Reform, Counter-

Reform. Princeton: Princeton University Press, 1983. 507 c.

Geraci $R$. P. Window on the East. National and Imperial Identities in Late Tsarist Russia. Cornell University Press, 2001. 356 c.

Haava U. Kristliku poliitika õnnelik aasta // Kirik ja Teoloogia. 2013. № 94.

Kenworthy $S$. The Heart of Russia: Trinity-Sergius, Monasticism and Society after 1825. New York: Oxford University Press, 2010. 528 c.

Kizenko N. A Prodigal Saint: Father John of Kronstadt and the Russian People. Univer-

sity Park: Pennsylvania State University Press, 2000. 376 c.

Kõrvalistest ametitest // Kasvatus. 1919. № 2.

Laar A. Meie kõige hädalisem vajadus // Uus Elu. 1932. № 4/5. P. 7-8.

Manchester L. Holy Fathers, Secular Sons: Clergy, Intelligentsia and the Modern Self

in Revolutionary Russia. DeKalb: The Northern Illinois University Press, 2008. 288 c.

Raudsepp A. Riia Vaimulik Seminar, 1846-1918. Tartu, 1998. 158 c.

Shevzov $V$. Russian Orthodoxy on the Eve of Revolution. New York: Oxford University Press, 2004. 358 c.

Skinner B. The Western Front of the Eastern Church. Uniate and Orthodox conflict in

$18^{\text {th }}$-century Poland, Ukraine, Belarus, and Russia. DeKalb: The Northern Illinois University Press, 2009. 295 c.

Staljunas D. Making Russians: Meaning and practice of Russification in Lithuania and

Belarus after 1863. Amsterdam; New York: Rodopi, 2007. 465 c.

Valk P. Ühest heledast laigust Eesti kooli ajaloos. Tallinn: Logos, 1997. 188 c.

Wagner $W$. The Transformation of Female Orthodox Monasticism in Nizhnii Novgorod Diocese, 1764-1929, in Comparative Perspective // Journal of Modern History. 2006. Vol. 78. № 12. P. 793-845.

Werth P. At the Margins of Orthodoxy: Mission, Governance and Confessional Politics in Volga-Kama region, 1827-1905. Cornell University Press, 2002. 285 c.

Werth P. The limits of Religious ascription: Baptized Tatars and the Revision of "Apostacy": 1840s - 1905 // The Russian Review. 2000. Vol. 59. № 4. P. 493-511. № 1 .

Õigeusu koolide kohta. Haridusministeeriumi seletus 27.12.1918. // Kasvatus. 1919.

Asutava Kogu poolt 2. mail 1920 a. vastuvõetud algkooli seaduse muutmise seadus. (1923). Riigi Teataja, 35/36.

Avalikkude algkoolide seaduse eelnõu. (1919). Kasvatus, 1, 6-16.

Coleman, H. (2014). Orthodox Christianity in Imperial Russia. A Source book on Lived Religion. Bloomington: Indiana University Press.

Dixon, S. (1993). Church, State and Society in Late Imperial Russia: the Diocese of St. Petersburg, 1880-1914. PhD diss. London: University of London.

Dixon, S. (2004). Sergii (Stragorodskii) in the Russian Orthodox Diocese of Finland: Apostasy and Mixed Marriages, 1905-1917. The Slavonic and East European Review, 82, $1,50-73$

Dolbilov, M. (2010). Russkij kraj, chuzhaya vera: e'tnokonfessional'naya politika imperii $v$ Litve $i$ Belorussii pri Aleksandre II. [Russian region, foreign faith: ethnoconfessional Imperial policy in Lithuania and Bielorussia]. Moscow: NLO. 
Eesti Ajaloo Arhiiv. F. 384, 1655, 2100.

Eesti Ajutise Valitsuse määrused koolide kohta. (1919). Kasvatus, 2.

Ernits, E. (1973). Õigeusu koolid 1840. aastatest 1880. aastate koolireformideni. Nõukogude kool, 10, 847-854.

Freeze, G. (1983). The Parish Clergy in Nineteenth-Century Russia: Crisis, Reform, Counter-Reform. Princeton: Princeton University Press.

Freeze, G. (1985). Handmaiden of the State? The Church in Imperial Russia Reconsidered. Journal of Ecclesiastical History, 36, 1, 82-102.

Gavrilin, A. (1999). Ocherki istorii Rizhskoj eparhii (19 vek) [Essays on the history of Riga diocese] Riga: Filokaliya.

Gan'zhin, S. (2002). Uroki mudrosti [Lessons of wisdom]. Zhurnal Moskovskoi Patriarkhii, 6. Retrieved from http://www.srcc.msu.su/bib roc/jmp/02/06-02/12.htm.

Geraci, R. P. (2001). Window on the East. National and Imperial Identities in Late Tsarist Russia. Cornell University Press.

Haava, U. (2013). Kristliku poliitika õnnelik aasta. Kirik ja Teoloogia, 94.

Kenworthy, S. (2010). The Heart of Russia: Trinity-Sergius, Monasticism and Society after 1825. New York: Oxford University Press.

Infant'ev, B. (2011). Nepriyazni i konflikty' mezhdu russkimi i laty'shskimi pravoslavny'mi seminaristami v 80-90e gg. Po romanu Pavila Gruzny' "Bursaki" [Tensions and conflicts between the Russian and Latvian Orthodox seminarists in 1880-90s. According to the novel of pavil Gruzna "Bursaki"]. Russkij mir i Latviya, 27, 160-163.

Isakov, S. G. (1974). Russkij yazy'k i literatura v uchebnyh zavedeniyah E'stonii XVII$X I X$ stoletij [Russian language in the teaching establishments in Estonia $17^{\text {th }}-19^{\text {th }} \mathrm{cc}$ ]. (Iss. 2.). Tartu.

Kizenko, N. (2000). A Prodigal Saint: Father John of Kronstadt and the Russian People. University Park: Pennsylvania State University Press.

Kõrvalistest ametitest. (1919). Kasvatus, 2.

Laar, A. (1932). Meie kõige hädalisem vajadus. Uus Elu, 4/5, 7-8.

Manchester, L. (2008). Holy Fathers, Secular Sons: Clergy, Intelligentsia and the Modern Self in Revolutionary Russia. DeKalb: The Northern Illinois University Press.

Otchet o sostoyanii pravoslavny'h narodny'h uchilishh Pribaltijskih gubernij za 19041905 uchebny'j god [Report on the conditions of the Orthodox elementary schools of the Baltic provinces for 1904-1905 school year]. (1906). Rizhskie eparhial'ny'e vedomosti. (Supplement to 11-12).

Prilozhenie k № 3 cirkuliarov po Rizhskomu uchebnomu okrugu za 1903 g. [Addition to the no. 3 of the circulars of riga educational district]. (1903). Riga.

Plyuhanov, B. V. (1993). RSHD v Latvii i E'stonii: Materialy' $k$ istorii Russkogo Hristianskogo Studencheskogo Dvizheniya [RSCM in Latvia and Estonia: Materials to the history of Russian Student Christian Movement]. [Paris]: YMCA-Press.

Raudsepp, A. (1998). Riia Vaimulik Seminar, 1846-1918. Tartu.

Sbornik rasporyazhenij po rizhskomu uchebnomu okrugu [The volume of the decrees for Riga educational District]. (1913). Riga.

Shevzov, V. (2004). Russian Orthodoxy on the Eve of Revolution. New York: Oxford University Press.

Shuvalova, E. (2000). Nachalo deyatel'nosti Russkogo Studencheskogo Hristianskogo Dvizheniya v E'stonii [Beginning of the activity of the Russian Student Christian Movement in Estonia]. In V. Boikov (Ed), Russkie v E'stonii na poroge XXI v. Proshloe, Nastoyashhee, budushhee. Tallinn.

Skinner, B. (2009). The Western Front of the Eastern Church. Uniate and Orthodox conflict in $18^{\text {th }}$-century Poland, Ukraine, Belarus, and Russia. DeKalb: The Northern Illinois University Press.

Staljunas, D. (2007). Making Russians: Meaning and practice of Russification in Lithuania and Belarus after 1863. Amsterdam, New York: Rodopi.

Valk, P. (1997). Ühest heledast laigust Eesti kooli ajaloos. Tallinn: Logos.

Vtoroj pasty'rskij s"ezd narvskoj eparhii v g. Narve 10-11.09.1939 [The second pastoral congress of Narva diocese in Narva]. (1939). Pravoslavny'i sobesednik, 9, 126.

Wagner, W. (2006). The Transformation of Female Orthodox Monasticism in Nizhnii Novgorod Diocese, 1764-1929, in Comparative Perspective. Journal of Modern History, $78,12,793-845$.

Werth, P. (2000). The limits of Religious ascription: Baptized Tatars and the Revision of "Apostacy": 1840s - 1905. The Russian Review, 59, 4, 493-511. 
Werth, P. (2002). At the Margins of Orthodoxy: Mission, Governance and Confessional Politics in Volga-Kama region, 1827-1905. Cornell University Press.

Õigeusu koolide kohta. Haridusministeeriumi seletus 27.12.1918. (1919). Kasvatus, 1.

The article was submitted on 20.09.2014

Ирина Пярт, $\mathrm{PhD}$

Эстония,

Тартуский университет

irina@paert.com

\section{Тоомас Швак}

аспирант

Эстония,

Тартуский университет

toomas.schvak@gmail.com
Irina Paert, $\mathrm{PhD}$

Estonia

University of Tartu

irina@paert.com

\author{
Toomas Schvak \\ Doctoral Student \\ Estonia \\ University of Tartu \\ toomas.schvak@gmail.com
}

